\title{
On the issue of practice-oriented education in distance learning
}

\author{
Maria N. Kovaleva ${ }^{1 *}$, Nadezhda V. Mrvich ${ }^{1}$, Elena V. Pakhonina ${ }^{1}$, Tatiana I. Sinitsyna ${ }^{1}$, \\ and Dmitriy $V$. Shibaev ${ }^{1}$ \\ ${ }^{1}$ North-West Institute (branch) of Kutafin Moscow State Law University (MSAL), Department of \\ Social Science, Humanities and Legal Computer Science, Moscow, Russia
}

\begin{abstract}
This article discusses the challenges of implementation and organization of practice-oriented education in the format of distance learning. The distance format included all spheres of life, thus promoting implementation of federal program of digital economy of the Russian Federation. The study is based on collection, analysis and generalization of data of the Russian and foreign experience of distance learning, including the technologies of artificial intelligence, virtual practices, education in the pandemic environment. Adaptation to the innovative distance format of communications revealed certain challenges, which should be investigated separately. The aim of this article is to determine and to propose optimum methodological solutions for practice-oriented education during learning of social humanitarian disciplines. The result of this work is a set of methods used for distance learning oriented at formation of professional competences for social humanitarian disciplines. Neural interfaces, digital educational platforms, digital didactics can be attractive for digital economy, business, investments. The significance of the work is in that the rich practice of various educational structures, experience of teachers, practicians and theoreticians, exchange at various discussion sites would allow to find the optimum solution to allowable usage of distance learning regarding the Russian Federal Educational Standard as well as development of methodological apparatus of social humanitarian disciplines.

Keywords: individual learning path, professional competences, methods of distance learning.
\end{abstract}

\section{Introduction}

One of the main requirements to universities at the present stage of social development is provision of practice-oriented learning in addition to fundamental theoretical training [1]. The necessity of implementation of this principle is determined by validation of the Governmental Decree of the Russian Federation No. 36 dated January 22, 2001 [2], according to which it was stipulated that the rules of development and validation of educational standards should involve participation of employers, this was aimed at combination of theoretical and practical approaches to learning into single process, when the employer

\footnotetext{
* Corresponding author: kovaleva.mn@bk.ru
} 
determined the competences of graduates required for further use in the employing company. The UN project Education for Sustainable Development [3] defines the development and improvement of practice-oriented learning in all educational spheres as the most important task. This is the approach to reduce employer's expenses for post-training or retraining of a new employee with respect to features of production process. This approach is applied for education in some Russian universities (MSU, MEPhI, Mendeleev University of Chemical Technology): application centers of large corporations operate at the universities (Yandex, Severstal, Playrix, YaShZ, and others), in which students undergo practical training and, while performing application tasks, form the required professional competences. In humanitarian universities, for instance in pedagogical, mandatory pedagogic practice is carried out; in juridical universities, legal clinics are maintained (practical consulting and presentation in legal authorities and courts of the first instance).

This principle is applied not only in Russia [4, 5]. In the education process of some foreign universities, practical orientation in education is used; for instance, the GLO-BUS system, which operates as a program methodological simulator of managerial activity in order to form skills of optimization of corporate incomes and expenses [6]. Japanese experience of lifetime employment, which played a significant role in Japanese economic miracle of 1950-1970-s, assumes existence of training centers in each large corporation (not necessarily an industrial one but also offering services: the most well-known example is Hakuhodo DY Holdings, which concentrated legal support of marketing and provides professional lawyers of various specifics), where senior students completed their education and became familiar with corporate culture, thus quite often being engaged by the company for life.

All these models and technologies are interesting regarding full-time form of study, when students are bound to university and teachers can act as direct tutors. And how to form the required professional competences and to carry out practice-oriented education in distance format?

\section{Methods}

This work was based on the methods of cultural and historical epistemology; comparative studies of practice-oriented education in the pandemic environment in the context of distance learning discussed in scientific publications; analysis and synthesis of practical material based on studies of social humanitarian disciplines during the distance learning in universities in spring-autumn, 2020, as well as interuniversity discussions with participation of other countries; method of dialectic interaction of singular, general, and universal upon analysis of formulation of the research conclusions.

\section{Discussion}

Digital transformation of education assumes interdisciplinary interaction, methods, formation of adaptive learning environment, proposes new requirements to teacher's model, student's model, use of intelligent learning assistants in virtual environment, which can act as moderators, controllers of learning process, virtual tutors, companions of continuous learning [7, 8]. Numerous questions arise: can virtual, alternate, mixed realities create individual learning path with practical orientation? How to develop it for each student so that it would be flexible, conceptual, oriented at specific student? What technologies, technical resources and aids should be involved? What is the readiness of society and employers for employment of such narrowly focused specialists? What to do if a student is not in demand at labor market? 
At present (autumn-winter 2020), thorough attention is paid to methods of formation of the required professional competences and implementation of practice-oriented learning during distance education. Development of digital didactics and digital humanitaristics becomes relevant, as well as application of neural technologies in education [9], collection of Big Data and monitoring of digital educational footprint [10]; the problem is brought forth concerning involvement of students into digital educational environment [11], holding attention, analysis of interest, creativity, emotionality, curiosity, purposefulness, cognitive processes [12] interrelated with memorization, forgetting, memory, conformity with sanitary and hygienic norms, etc.

Herewith, this is accompanied by certain problems related, firstly, with the lack of full visual contact of teacher and students due to limited use of digital information infrastructure, technical equipment of educational establishments, the absence of personal digital devices. This can hardly be achieved by such software as Zoom, Skype and the like. Secondly, this is caused by closure or restricted attendance of educational entities, limited opportunities of work, for instance, of legal consultations (clinics) with customers. Thirdly, tests of practical knowledge of students are not fully objective, since in the distance format, students have unlimited amount of reference material, opportunity to control independent actions (for instance, solution to special case, problematic situation, case assignment, arrangement of procedural documents) is very difficult and requires for high technical equipment, various digital tools. And, finally, skills of operation with PC, low digital competence of staff and students, low-speed internet, features of adjustment from various technical aids, fine software tuning and other technical problems: all this creates difficulties in acquisition of required knowledge, skills and habits by students, mastering of professional competences.

These negative issues can be eliminated by means of the following methods, which assume high level of students' independence upon distance learning [13, 14]:

- Provision of not only solution to cases for each topic but also their independent individual preparation, solution. In this way, the teacher significantly limits possibility to copy solutions from each others, since the cases and their solutions are characterized by individual features [15-17]: for instance, preparation of documents, their demonstration; reconstruction of events, forecasting of situation and consequences; designing, simulation, development of problematic situations; business game; writing comments, reviews, essay; selection of links and references, illustrations.

- Compilation of thematic portfolio, individually or in group, where the roles and performed functions, types of work are distributed. In addition, students are forced to coordinate the prepared document packages between performers; thus, the interrelations in the group are retained [18]. This format can be widely applied in projects.

- Opportunities of software for distance learning, advanced training, webinars, online conferences, round table discussions (Zoom, Skype, etc.) can be used to engage faculty practitioners not only from Russia but from neighboring countries and beyond. This improves scientific interaction among practitioners, theoreticians, representatives of various scientific areas, which expands interdisciplinary experience exchange, attracts young researchers, allows to reveal talented persons. Practitioners can be found both in main universities, where they teach, and at forums, for instance, of practicing lawyers (https://zakon.ru/ - social networks of lawyers, https://lfacademy.ru/ - education for law officers, https://pravorub.ru/ - professional community of law officers and lawyers).

- The distance format allows to create comfort psychological and emotional environment, where students irrespective of their health state (health level, physical and intelligent features) can realize themselves on equal basis. Individual learning mode significantly reduces stresses, for instance, necessity to compete, to work in a hurry or with delays; the learned material can be reviewed at any time, since there exists electronic record of online lesson. Information, study material are presented in the new for students format, similar 
to usual content from Internet, for instance: audio presentations, video lectures, podcasts, computer testing with instant evaluation and description of errors, opportunity to use not only desktop PC but smartphone as well; distance competitions; using Internet links to popular and thematic portals, social networks; simulators, virtual reality modules; smartphone applications to control and arrange, for instance, healthy sleep, nutrition, physical activity, exercising [19].

- Rapid feedback and reflection by means of chats, photo and video recording of home assignments or their demonstration, online consultations, responses with demonstration of presentations, video fragments, etc. In particular, personified model discloses individual potential of any student, allows to account for peculiar features, existing experience, interests. Such model of lessons does not exclude, among others, monitoring of function state of students [20].

\section{Conclusion}

The distance education is becoming a common and natural form of learning. However, another issue is how and in what ratios it will correlate with direct learning. It could be assumed that for extramural training, distance forms of advanced training and retraining, such type is very useful and expedient. As for the secondary education and the first-year university courses, most likely, only combined learning is allowable, since the skills of independent learning are not sufficiently formed. In addition, much depends on practical orientation of educational course, university, digital skills of staff, technical equipment of establishments, digital culture of users, diversity of digital didactics and its efficiency. Nowadays this is a very relevant field of study for various sciences, as well as for attracting attention of business and authorities [21, 22]. The versatile practice of application, analysis of errors and opportunities, online communications and experience transfer at discussion sites would allow to find the optimum solution to practice-oriented learning in distance format.

\section{References}

1. Yu. B. Luneva, O.I. Vaganova, Zh. V. Smirnova, Innovative Economy Prospects for Development and Improvement, 6(32), 122-126 (2018)

2. O vnesenii izmeneniya v prilozheniye $\# 23 \mathrm{k}$ gosudarstvennoy programme Rossiyskoy Federatsii "Razvitiye obrazovaniya": Postanovleniye Pravitel'stva RF ot 22.01.2020 №36 [On amendments to Appendix No. 23 to the State Program of the Russian Federation "Development of Education": Decree of the Government of the Russian Federation of January 22, 2020 No. 36. (2020). Accessed on: December 10, 2020. [Online]. Available: http://www.consultant.ru/document/cons_doc_LAW_343816/

3. "Obrazovaniye dlya ustoychivogo razvitiya": Proyekt resheniya, prinyatyy 57-oy sessiyey General'noy Assamblei OON 20 dekabrya 2002g. [Education for Sustainable Development: Draft decision adopted by the 57th session of the UN General Assembly on December 20, 2002.]. Decisions of the 57th session (2002). Accessed from https://www.un.org/ru/ga/57/docs/57dec.shtml

4. J.E. Aoun, Robot-Proof: higher education in the age of artificial intelligence, 181-183 (MIT Press, Cambridge, MA, 2017)

5. J.C. Brown, The Online Journal of Distance Education and e-Learning, 3(1), 1-7 (2015)

6. C. Miller, Marketing News, 27, 1-12 (1993)

7. H. Kentnor, Curriculum and Teaching Dialogue, 17(1-2), 21-34 (2015) 
8. S. Palvia, Journal of Global Information Technology Management, 21(4), 233-241 (2018)

9. V.B. Voinov, Online discussion "Neurotechnologies in the educational process: a step from fantasy to reality". (2020). Accessed on: December 10, 2020. [Online]. Available: https://youtu.be/mRFNfiq84gY

10. I. A. Kizhner. Online discussion "Data analytics in education". (2020). Accessed on: December 10, 2020. [Online]. Available: https://www.youtube.com/watch? $\mathrm{v}=\mathrm{cx} 50 \mathrm{eVblMWo \& t}$

11. S.L. Shishkin, Online discussion "Neurotechnologies in the educational process: a step from fiction to reality". (2020). Accessed on: December 10, 2020. [Online]. Available: https://youtu.be/mRFNfiq84gY

12. D.G. Shtennikov, Online discussion "Neurotechnologies in the educational process: a step from fiction to reality". (2020). Accessed on: December 10, 2020. [Online]. Available: https://youtu.be/mRFNfiq $84 \mathrm{gY}$

13. Z. Smirnova, O. Vaganova, S. Shevchenko, A. Khizhnaya, M. Ogorodova, M. Gladkova, IEJME. Math. Educ., 11(10), 3469-3475 (2016)

14. Z.V. Smirnova, M.V. Mukhina, L.I. Kutepova, M.M. Kutepov, O.I. Vaganova, Advances in Intelligent Systems and Computing, 622, 187-193 (2018). https://doi.org/10.1007/978-3-319-75383-6_24

15. L. K. Ilyashenko, O. I. Vaganova, Z. V. Smirnova, E. P. Sedykh, O. G. Shagalova, International Journal of Mechanical Engineering and Technology, 9(4), 1029-1035 (2018)

16. L. K. Ilyashenko, M. P. Prokhorova, O. I. Vaganova, Z. V. Smirnova, E. A. Aleshugina, International Journal of Mechanical Engineering and Technology, 9(4), 1080-1087 (2018)

17. L. K. Ilyashenko, O. I. Vaganova, Z. V. Smirnova, M. L. Gruzdeva, A.V. Chanchina, International Journal of Mechanical Engineering and Technology, 9(4), 1088-1096 (2018)

18. M. Firat, H. Kilinc, T. Yuzer, Journal of Computer Assisted Learning, 34(1), 63-70 (2018)

19. N.V. Vasenkov, E. Sh. Minnibaev, sovremennyye tendentsii razvitiya nauki i tekhnologiy [Modern trends in the development of science and technology], 10, 72-75 (2016)

20. D.V. Shibaev (Ed.), Obrazovatel'nyye tekhnologii v sovremennom vuze: voprosy teorii i praktiki: kollektivnaya monografiya [Educational technologies in a modern university: theory and practice: a collective monograph] (North-Western Institute (branch) of Kutafin Moscow State Law University, Development Fund of University Branch in Vologda, Vologda, 2020)

21. E. V. Pakhonina, T. I. Sinitsyna, On the problem of human understanding in the era of digitalization, in Science and Society. The collection includes 14th International Scientific and Practical Conference "Science and Society", 27-29 November 2019, London, UK, 180-184 (2019)

22. O. I. Vaganova, Z. V. Smirnova, M. V. Mukhina, M. M. Kutepov, L. I. Kutepova, T. L. Chernysheva, Journal of Entrepreneurship Education, 20(3), 35540422 (2017) 